\title{
MANAJEMEN PEMBELAJARAN BERBASIS TEKNOLOGI INFORMASI DAN KOMUNIKASI DI SEKOLAH MENENGAH PERTAMA NEGERI 3 SUNGAI LILIN
}

\author{
MUHAMMAD EZRA KURNIAWAN ${ }^{1}$, YASIR ARAFAT ${ }^{2}$, SYAIFUL EDDY ${ }^{3}$ \\ ${ }^{1}$ SMP Negeri 3 Sungai Lilin, ${ }^{2}$ Universitas PGRI Palembang \\ Email: ezrakurniawan40@gmail.com
}

\begin{abstract}
ABSTRAK
Penelitian ini bertujuan untuk menganalisis dan mendeskripsikan tentang manajemen pembelajaran berbasis teknologi informasi dan komunikasi di SMP Negeri 3 Sungai Lilin. Penelitian ini menggunakan metode kualitatif deskriptif. Hasil penelitian menyimpulkan bahwa kepala sekolah bertanggung jawab serta berperan penting dalam manajemen pemebelajaran berbasis teknologi informasi dan komunikasi melalui perencanaan program jangka pendek dan jangka panjang. Melakukan pengorganisasian dan koordinasi kepada pendidik, tenaga pendidik dan peserta didik untuk dapat memanfaatkan pembelajaran berbasis TIK. Serta melakukan evaluasi untuk melihat manfaat dan kendala apa saja dari pemanfaatan pembelajaran berbasis teknologi informasi dan komunikasi di SMP Negeri 3 Sungai Lilin. Hasil evaluasi menunjukkan manfaat yang dirasakan dari pemanfaatan pembelajaran berbasis teknologi informasi dan komunikasi dari bermacam produk TIK yang sudah ada memberikan inovasi serta kemudahan dalam aktifitas sekolah terutama dalam aktifitas proses pembelajaran seperti, mempermudah pendidik/guru dalam mengelola manajemen kelas berupa pembuatan perangkat pembelajaran, silabus , RPP dan mengelola hasil nilai peserta didik. Serta dapat dijadikan sebagai salah satu inovasi sumber belajar bagi pendidik dan peserta didik. Kendala yang dirasakan dari pemanfaatan pembelajaran berbasis TIK mahalnya sarana prasarana TIK sehingga memerlukan perencanaan program jangka panjang untuk melengkapi sesuai standar sekolah berbasis TIK serta masih belom meratanya jaringan internet.
\end{abstract}

Kata Kunci : TIK, Model Pembelajaran, Metode Pembelajaran, Manajemen

\section{PENDAHULUAN}

Penggunaan fungsi manajemen dalam proses pembelajaran melalui (perencanaan, organisasi, pelaksanaan, dan kontrol) merupakan cara untuk mengatur, mengendalikan, mengkomunikasikan dan memanfaatkan sumber daya yang ada agar dapat mencapai tujuan secara efektif dan efesien (Kristiawan, Safitri \& Lestari, 2017:1). Manajemen pembelajaran merupakan proses pembelajaran untuk mencapai keberhasilan siswa dalam menerima pelajaran, serta guru harus mampu menciptakan kondisi yang membuat siswa merasa nyaman dalam proses belajar, merasa senang belajar di kelas. Ini akan dicapai melalui manajemen pembelajaran yang baik. Menurut Wirastuti (2020:17) ditemukan bahwa manajemen pembelajaran yang baik mampu mempengaruhi efektivitas dalam proses mencapai tujuan pembelajaran.

Pembelajaran dapat didefinisikan sebagai suatu peristiwa yang dirancang dan direncanakan untuk menggiatkan dan mendukung kegiatan belajar peserta didik dalam suatu proses pembelajaran. Menurut (Gasong, 2018:10) Pembelajaran juga dapat diartikan sebagai suatu proses mengatur, mengorganisasi lingkungan yang ada di sekitar serta memberikan bimbingan atau bantuan kepada peserta peserta didik sehingga dapat menumbuhkan dan mendorong peserta didik agar mampu mencapai tujuan dalam suatu proses pembelajaran.

Menurut Kartika, Husni \& Milah (2019:114) Pelaksanaan kegiatan dalam bidang pendidikan terutama dalam proses pembelajaran membutuhkan sarana dan prasarana, baik dari infrastruktur dan sumber daya manusia. Sepeti tenaga pendidik yang berkompeten dan profesional, ketersediaan lokal kelas, perpustakaan, lapangan, dan unit kesehatan sekolah, juga kurikulum, bahan ajar, dan media pembelajarannya. Salah satu inovasi kegiatan pembelajaran yang dilakukan oleh satuan kelas atau sekolah adalah pemanfaatan Teknologi Informasi dan Komunikasi yang selanjutnya disingkat TIK. 


\section{STRATEGY : Jurnal Inovasi Strategi dan Model Pembelajaran Vol 1. No 1. Juli Tahun 2021 e-ISSN : 2798-5466 P-ISSN : 2798-5725}

Pada dunia pendidikan Indonesia, globalisasi memberi dampak keharusan perubahan pada cara mengajar guru yang dulunya bersifat tradisional berbasis paper menjadi kini berbasis teknologi informasi dan komunikasi (TIK). Menurut Aka (2017:28) Kehadiran TIK dalam dunia pendidikan memungkinkan terwujudnya pembelajaran yang efektif, menyenangkan, dan melibatkan siswa secara aktif. Kemampuan keutuhan TIK dalam menyampaikan pesan diakui sangat signifikan. Teknologi informasi dan komunikasi (TIK) adalah sesuatu teknologi baik perangkat keras (hardware) maupun perangkat lunak (software) yang digunakan untuk mengelola data/informasi dan komunikasi. Dalam prakteknya teknologi diwakili oleh komputer (perangkat keras) dan program-program aplikasi (perangkat lunak). Data/informasi yang dikelola dan dihasilkan dalam bentuk berbagai media, seperti teks, grafik, gambar diam, foto, film, animasi, dan simulasi. Cara-cara berkomunikasinya memungkinkan untuk dilakukan secara maya (Aka, 2017:30).

Manfaat yang didapatkan oleh dunia pendidikan dengan memanfaatkan teknologi informasi dan komunikasi dalam pembelajaran, yaitu: mampu meningkatkan mutu pendidikan dengan membuka lebar-lebar akses ilmu pengetahuan dan teknologi informasi dalam rangka penyelenggaraan pendidikan yang efektif, berkualitas, dan menyenangkan. Pembelajaran dengan memanfaatkan teknologi informasi dan komunikasi juga dapat merangsang keaktifan siswa, meningkatkan daya tarik siswa terhadap proses pembelajaran sehingga dapat meningkatkan motivasi dan perhatian siswa (Muhibudin, 2017:68).

Pemanfaatan TIK dalam bidang pendidikan banyak memberikan keuntungan bagi perkembangan dan kemajuan dunia pendidikan TIK telah mendorong lahirnya sistem pembelajaran jarak jauh sehingga para peserta didik dapat mengakses modul pelajaran lewat jaringan internet, mengikuti kegiatan pembelajaran di rumah tanpa harus hadir di kelas, bahkan dapat mengikuti kegiatan persekolahan maupun kursus jarak jauh, semua kegiatan pembelajaran tak dibatasi oleh jarak, ruang, dan waktu. Bahkan bagi peserta didik, penggunaan TIK telah membantu mereka dalam pencarian segala bentuk informasi dan data sebagai sumber penunjang pembelajaran di sekolah dan penyelesaian tugas-tugas di sekolah (Fauziah dan Hedwig, 2010: 83).

Selanjutnya perkembangan TIK telah memberi pengaruh serta peluang terhadap dunia pendidikan. Ada beberapa pengaruh dalam pemanfaatan TIK terhadap proses pembelajaran, yaitu: (1) dari pelatihan ke penampilan, (2) dari ruang kelas menjadi kapan saja dan di mana saja, (3) dari kertas menjadi online, (4) dari fasilitas fisik menjadi fasilitas jaringan kerja (Huda, 2020:144). Menurut Aka (2017:32) fungsi TIK memberikan kemudahan bagi guru dapat digunakan untuk membantu pekerjaan administratif (Word processor \& Kebutuhan Wajib Tingkat Dasar, Spreadsheet), dapat digunakan untuk membantu mengemas bahan ajar (Multimedia), dapat digunakan untuk membantu proses manajemen pembelajaran, dapat digunakan untuk dukungan teknis dan meningkatkan pengetahuan agar dapat mewujudkan self running creation melalui jaringan internet, serta sosial media untuk mempermudah jaringan komunikasi.

Selain melihat manfaat yang besar, di Indonesia masih banyak sekolah yang belum memaksimalkan memanfaatkan pembelajaran berbasis teknologi informasi dan komunikasi karena berbagai hambatan dan tantangan. Hal ini sejalan dengan hasil penelitian Kurniawan (2019:28) menjelaskan hambatan terbesar yang dihadapi sekolah belum memiliki sarana prasarana yang memadai, sedikitnya tenaga ahli di bidang teknologi, hambatan lainnya adalah koneksi internet yang tidak stabil serta sekolah belum memiliki pembangkit listrik cadangan sehingga mengakibatkan ketergantungan pada aliran listrik dari PLN sangat tinggi. Adapun hambatan dari sisi sumber daya manusia adalah beberapa guru yang kemampuan menggunakan TIK-nya masih belum maksimal.

Beberapa penelitian relevan diantranya, penelitian yang telah dilakukan Winda (2016:61) menjelaskan dalam hasil penelitiannya. Kedudukan TIK dalam pembelajaran antara lain: (a) Mempermudah kerjasama pendidik dan peserta didik serta menghilangkan batasan ruang, jarak, dan waktu, (b) Berbagi informasi (sharing information) sehingga mempercepat 


\section{STRATEGY : Jurnal Inovasi Strategi dan Model Pembelajaran \\ Vol 1. No 1. Juli Tahun 2021 e-ISSN : 2798-5466 P-ISSN : 2798-5725}

perkembangan ilmu pengetahuan, dan (c) Menyediakan pembelajaran yang mudah diakses oleh banyak orang (virtual school), berisi berbagai informasi yang berkaitan dengan sekolah.

Maria dan Sediyono (2017:70) menjelaskan hasil penelitiannya tentang pengembangan model manajemen pembelajaran berbasis TIK di sekolah dasar belum efektif. Perlu dukungan pihak sekolah untuk kesiapan SDM, infrastruktur dan peserta didik. Bagi guru perlu kerjasama dan komunikasi pihak intern dan ekstern untuk meningkatkan kemampuan TIK. Bagi kepala sekolah perlu meningkatkan supervisi yang berkaitan penerapan pembelajaran TIK, membentuk tim IT, dan memikirkan strategi untuk menyiapkan dana bagi peningkatan infrastruktur TIK dan perwatannya.

Nurvitasari (2018:48) Hasil penelitian menunjukkan bahwa sebagian besar guru sudah memanfaatkan TIK dalam pembelajaran kimia, tetapi masih ada Kendala yang dihadapi oleh guru diantaranya adalah terbatasnya fasilitas TIK seperti komputer, LCD proyektor, dan jaringan internet. Serta kurangnya pengetahuan dan keterampilan guru dan siswa untuk memanfaatan TIK dalam pembelajaran dan menjadikan pemanfaatan TIK dalam proses pembelajaran kimia SMA di Distrik Merauke menjadi kurang maksimal.

Penelitian yang telah dilakukan Bali (2019:38) Menunjukkan pemanfaatan TIK dalam pembelajaran jarak jauh (distance learning) sangat membantu dalam proses pembelajaran karena tidak harus melakukan tatap muka. Media komunikasi yang dapat digunakan meliputi; audio atau kaset video, multimedia, CD-ROM, jaringan internet, dsb. Teknologi komunikasi memiliki kecanggihan yang optimal untuk menjadi media dalam penyampaian materi/konsep, tugas berkala, ujian semester, bahkan dalam penyelesaian tugas akhir. Penilaian dapat menggunakan dua cara, yaitu penilaian portofolio dan penilaian terintegrasi.

Penelitian yang telah dilakukan partono (2020:109) berdasarkan interpretasi dan hasil penelitian, disimpulkan bahwa sekolah telah menyelenggarakan tahapan dalam manajemen strategis yang memungkinkan sekolah memiliki profil yang berkualitas. Dampak pemanfaatan TIK yang efektif untuk sekolah adalah pencapaian manajemen sekolah yang efektif, sesuai dengan Standar Pendidikan Nasional, yang dicirikan oleh perencanaan, implementasi, kontrol, dan evaluasi TIK sekolah yang efektif.

Sejalan dengan program dan kebijakan yang telah dicanangkan oleh pemerintah pusat. Kabupaten Musi Banyuasin melalui Dinas Pendidikan juga menyambut tantangan dan program mengenai pembelajaran berbasis teknologi dan informasi dengan melakukan pemetaan terhadap sekolah menengah pertama yang memiliki potensi dan proses pembelajaran yang siap menjawab tantangan revolusi industri 4.0 melalui pemanfaatan pembelajaran berbasis teknologi dan informasi. Berdasarkan data dari Bidang Pendidikan Menengah pertama Dinas Pendidikan Kabupaten Musi Banyuasin terdapat 200 SMP Negeri/Swasta yang terdiri dari 109 SMP Negeri dan 91 SMP Swasta. Peneliti memilih objek penelitian di SMP Negeri 3 Sungai lilin terletak di alamat JL. Palembang-Jambi Km 121 Desa Sumber Rezeki Rt 13 Rw 5 Kec. Sungai Lilin Kab. Musi Banyuasin Provinsi Sumatera Selatan, dan merupakan sekolah yang sudah lama berdidiri sejak tahun 1985 sampai sekarang. SMP Negeri 3 Sungai Lilin memiliki akreditasi A dan merupakan salah satu sekolah yang bersungguh sungguh untuk mengimplementasikan pembelajaran berbasis teknologi informasi dan komunikasi di sekolah.

Berbagai usaha dilakukan sekolah, mulai dari melengkapi infrastruktur, sumber daya manusia, sistem, serta hubungan kerjasama dengan pihak luar sekolah untuk mendukung dan mengimplementasikan pembelajaran berbasisis TIK di sekolah SMP Negeri 3 Sungai Lilin. Beberapa usaha yang telah dan sedang dilakukan antara lain tersedianya ruangan laboratorium komputer yang terdiri dari 60 unit komputer, serta memberikan pelatihan mengenai pembuatan media pembelajaran serta beberapa keterampilan yang perlu dimiliki guru terkait pembelajaran berbasis teknologi informasi dan komunikasi. Selain itu, masih banyak hal lain terkait pembelajaran berbasis teknologi informasi dan komunikasi di SMP Negeri 3 Sungai lilin. 


\section{STRATEGY : Jurnal Inovasi Strategi dan Model Pembelajaran Vol 1. No 1. Juli Tahun 2021 e-ISSN : 2798-5466 P-ISSN : 2798-5725}

Berdasarkan hasil paparan diatas dapat disimpulkan, perlunya melakukan penelitian mengenai manajemen pemanfaatan TIK dalam proses pembelajaran karena memiliki potensi pembelajaran yang siap menjawab tantangan revolusi industri 4.0 melalui pemanfaatan pembelajaran berbasis teknologi dan informasi. Sehingga peneliti tertarik melakukan penelitian yang mengungkap lebih jauh mengenai manajemen pembelajaran berbasis teknologi informasi dan komunikasi sehingga penelitian ini mengangkat judul "Manajemen Pembelajaran Berbasis Teknologi Informasi dan Kominikasi di SMP Negeri 3 Sungai Lilin".

\section{METODE PENELITIAN}

Penelitian ini menggunakan pendekatan penelitian kualitatif deskriptif. Menurut Bogdan dan Taylor metodologi kualitatif adalah prosedur penelitian yang menghasilkan data deskriptif berupa kata-kata tertulis atau lisan dari orang-orang dan perilaku yang dapat diamati (Moleong, 2011:5). Penelitian kualitatif merupakan suatu penelitian di mana seorang peneliti memperoleh data dari latar belakang alamiah (natural setting) secara holistik guna menentukan, menggambarkan, dan menguji kebenaran suatu pengetahuan melalui metode ilmiah yang dideskripsikan ke dalam kata-kata, kalimat atau gambar yang ada atau lisan dari orang-orang atau perilaku orang yang menjadi objek penelitian (Sugiyono, 2017:39).

Melalui pendekatan penelitian kualitatif deskriptif, peneliti menginvestigasi bagaimana strategi kepala sekolah dalam mendukung pemanafaatan pembelajaran berbasisi TIK serta kesiapan guru memanfaatkan pembelajaran berbasisi TIK. Peneliti melakukan beberapa kegiatan dalam pengumpulan data dengan menggunakan beberapa instrument, yaitu peneliti sendiri, informasi dari teman yang menjadi tenaga pendidik di SMP Negeri 3 Sungai Lilin, buku catatan serta alat merekam. Untuk mendapatkan data dari sumber data primer dan sekunder, peneliti melakukan observasi, wawancara dan dokumentasi yang selanjutnya akan dianalisis menggunakan analisis Mils and Hubemeni. Setelah data-data diperoleh, peneliti memahami, menelaah, dan kemudian menafsirkan arti dari hasil yang didapat di lapangan. Jadi peneliti mencari informasi dari apapun yang ditemui di lapangan untuk mendukung data. Semua data yang diperoleh akan dipelajari dan dicatat oleh peneliti.

\section{HASIL DAN PEMBAHASAN}

Penelitian ini bertujuan untuk mendeskripsikan manajemen pembelajaran berbasis TIK di SMP Negeri 3 Sungai Lilin. Dimana pengaruh perkembangan teknologi di era golbalisasi saat ini sebagai dampak perkembangan zaman sejak abad ke 21 telah memasuki semua aspek kehidupan saat ini. Perkembangan teknologi dan sumber daya menjadi semakin cepat, informasi dan komunikasi semakin canggih dan instan, serta setiap aspek kehidupan dihadapkan pada berbagai peluang dan sekaligus tantangan yang semakin kompleks dalam memanfaatkan teknologi. Kemajuan teknologi telah mempengaruhi berbagai aspek kehidupan terutama dalam dunia pendidikan.

Temuan hasil penelitian mengenai manajemen kepala sekolah berkaitan dengan perencanaan, pengorganisasian, koordinasi, dan pengawasan dalam memaksimalkan pembelajaran berbasis teknologi informasi dan komunikasi di SMP negeri 3 Sungai Lilin. Hal ini dapat disimpulkan bahwa kepala sekolah SMP Negeri 3 Sungai lilin bertanggung jawab dalam memenuhi sarana prasarana dalam proses pembelajaran terutama dalam proses pembelajaran berbasis TIK melalui perencanaan jangka pendek dan jangka panjang.

Hal ini sejalan dengan penjelasan Damayani, Arfat, dan Eddy (2020:46) Kepala sekolah merupakan salah satu pendorong sekolah untuk mewujudkan visi, misi, tujuan dan sasaran sekolahnya melalui program program yang dilaksanakan secara terencana dan bertahap melalui perencanaan yang berkualitas. Rivayanti, Arafat, dan Puspita (2020:12) menerangkan dengan kemampuan manajerial yang baik diharapkan setiap kepala sekolah mampu melaksanakan pembinaan dengan menjadi pendorong dan penegak disiplin bagi para guru agar mampu menunjukkan profesionalisme dalam menjalankan tugas dan fungsinya sebagai guru melalui perencanaan program kepala sekolah. 


\section{STRATEGY : Jurnal Inovasi Strategi dan Model Pembelajaran Vol 1. No 1. Juli Tahun 2021 e-ISSN : 2798-5466 P-ISSN : 2798-5725}

Hal ini sejalan dengan hasil penelitian Wardani (2014:204) tentang manajemen kepala sekolah dalam menyediakan sarana prasarana sekolah terutama tentang pemanfaatan TIK bahwa Kepala sekolah berperan dalam memfasilitasi sarana prasarana, melengkapi fasilitas, dan kepala sekolah berperan dalam menyediakan sarana prasrana untuk menunjang pembelajaran berbasis TIK yang diprogramkan melalui perncanaan jangka pendek maupun jangka panjang dengan baik melalui progam-progam pengembangan sekolah yang berkualitas.

Selain memenuhi kebutuhan sarana dan prasaran TIK kepala Sekolah SMP Negeri 3 Sungai Lilin juga mendukung sumber daya manusia (SDM) terdiri dari pendidik dan peserta didik untuk antusias menerapakan pembelajaran berbasis TIK. Dukungan (SDM) yang dilakukan terhadap pendidik/tenaga pendidik dengan melakukan pengorganisasian dengan menempatkan sesuai tanggung jawab dan kemampuannya. Serta melakukan koordinasi dengan mengadakan pelatihan-pelatihan yang berkaitan dengan pemanfaatan TIK dalam proses pembelajaran. Serta dukungan untuk peserta didik melalui hasil observasi dan dokumentasi pada hasil penelitian salah satunya mengkampanyekan literasi digital dengan memberi kesempatan peserta didik untuk mengikuti lomba literasi digital.

Sejalan dengan itu, bagi dunia pendidikan dukungan manajemen sumber daya manusia (SDM) yang kuat dan komitmen kepala sekolah merupakan hal yang mutlak untuk keberhasilan organisasi secara menyeluruh serta pengembangan dan usaha meraih keunggulan kompetitif dan peningkatan mutu pendidikan (Utamy, Ahmad dan Eddy, 2020:227). Selain melengkapi saran dan prasaran pembelajaran berbasis TIK sejalan dengan hasil penelitian Suriansyah (2015:5) menejelaskan sebagai kepala sekolah juga harus melakukan pengorganisasian dan koordinasi melalui dukungan peningkatan sumber daya manusia (SDM) baik tenaga kependidikan, tenaga pendidik (guru), dan peserta didik (siswa) untuk mampu menggunakan sarana dan prasarana pembelajaran berbasis TIK dan mengaplikasikan TIK sebagai media pembelajaran maupun sebagai sumber belajar. Peningkatan kemampuan dan keterampilan ini merupakan prasyarat yang harus dilakukan dan hal yang terpenting adalah merubah paradigma berfikir guru, budaya guru dalam pembelajaran dan budaya siswa dalam belajar untuk terbuka dalam memanfaatkan TIK pada proses pembelajaran.

Temuan hasil penelitian mengenai peluang dan manfaat pembelajaran berbasis TIK di SMP Negeri 3 Sungai Lilin dapat disimpulkan bahwa kepala sekolah SMP Negeri 3 Sungai Lilin menjelaskan peluang dan pemanfaatan bermacam-macam produk TIK yang sudah ada memberikan inovasi serta kemudahan dalam aktifitas sekolah terutama dalam aktifitas proses pembelajaran. Kepala sekolah SMP Negeri 3 Sungai Lilin juga menjelaskan dengan berbagai macam produk TIK memberikan kemudahan dalam menyampaikan informasi dan komunikasi untuk kepentingan sekolah seperti rapat internal/eksternal, penyimpanan data sekolah dan sebagainya.

Hal ini sejalan dengan penelitian Budiman (2017:36) menjelaskan dalam pemanfaaatan teknologi informasi dan komunikas berkaitan dengan seluruh peralatan teknis untuk memproses data dan menyampaikan informasi. TIK mencakup dua aspek yaitu teknologi informasi dan teknologi komunikasi. Teknologi informasi meliputi segala hal yang berkaitan dengan proses, penggunaan produk teknologi sebagai alat bantu, manipulasi, dan pengelolaan informasi berupa perangkat keras (Hardware). Sedangkan teknologi komunikasi adalah segala sesuatu yang berkaitan dengan penggunaan alat bantu berupa perangkat lunak (software) untuk memproses dan mentransfer data kemudian dikomunikasikan dari perangkat satu keperangkat lainnya.

Berdasarkan temuan pada hasil penelitian tentang pemnafaatan TIK pada proses pembelajaran dapat ditarik kesimpulan bahwa keterlibatan TIK dalam proses pembelajaran membuka peluang untuk mempermudah dalam mengelola manajemen kelas berupa pembuatan perangkat pembelajaran, silabus , RPP dan mengelola hasil nilai peserta didik dengan mengunakan komputer ataupun laptop serta melalui pemanafaatan TIK dengan 
berbagai produk yang tersedia dapat dijadikan sebagai sumber belajar bagi pendidik dan peserta didik.

Sejalan dengan hasil temuan Zulkarnain (2015:77) menjelaskan manajemen kelas berbasis TIK menghendaki paling sedikit tiga tahap, yakni langkah persiapan, pelaksanaan, dan evaluasi. Tahap persiapan adalah langkah menyiapkan perangkat pembelajaran menggunakan perangkat keras berupa komputer ataupun laptop. Tahap pelaksanaan adalah langkah melaksanakan pembelajaran dengan memilih salah satu program TIK yang menjadi media pembelajaran sebagai sumber belajar. Tahap evaluasi adalah tahap melakukan refleksi terhadap pelaksanaan proses belajar-mengajar yang telah dilaksanakan dengan menggunakan pendekatan TIK.

Temuan hasil penelitian yang telah dilakukan tentang pembelajaran berbasis TIK di SMP Negeri 3 Sungai Lilin bahwa kegiatan belajar mengajar dimana guru memanfaatkan TIK dalam proses pembelajaran salah satunya dengan melakukan seperti pembuatan Slide presentasi menggunakan Program Power Point yang diproyeksikan melalui proyektor LCD. Selanjutnya untuk penyampaian bahan pelajaran yang disajikan kepada sisiwa dapat berupa gambar-gambar yang menarik, audio visual dan lain sebagainya. Hal ini dapat mendukung siswa mendapatkan pengalaman belajar yang lebih menarik dan menyenangkan. Temuan pada penelitian ini sejalan dengan beberapa penelitian berikut, yang pertama penelitian Utami (2017:58) Penggunaan Media Pembelajaran proyektor LCD menggunakan Program Power Point berpengaruh terhadap hasil belajar matematika siswa. Sehingga dapat disimpulkan bahwa hasil belajar matematika siswa yang diajar dengan media Pembelajaran Proyektor LCD menggunakan Program Power Point lebih baik dari hasil belajar matematika siswa yang diajar dengan menggunakan media pengajaran kertas karton.

Temuan selanjutnya oleh penelitian Al-mutaqin, Mansur, dan Sulistiono (2020:89) Kegiatan pembelajaran PAI dengan media proyektor berpengruh terhadap motivasi belajar siswa Kelas VII, hal ini terbukti dengan aktifitas belajar peserta didik di dalam kelas lebih aktif, suasana kelas yang kondusif, daya serap peserta didik akan materi yang disampaikan oleh guru lebih tinggi, peserta didik lebih giat dalam belajar mata pelajaran PAI, materi pelajaran tertuntaskan, serta guru PAI lebih kreatif dalam memilih dan mendisain media yang akan digunakan sebagai sarana menyampaikan materi pelajaran PAI.

Temuan hasil penelitian selanjutnya yang telah dilakukan tentang pembelajaran berbasis TIK di SMP Negeri 3 Sungai Lilin bahwa dengan berbagai macam produk TIK yang sudah ada saat ini memungkinkan untuk dimanafaatkan dan membantu dalam proses pembelajaran. Terutma pada saat pandemi covid-19 sekarang siswa tetap bisa melakukan pembelajar meskipun tidak melalui tatap muka disekolah. Namun, tetap bisa melakukan pembelajaran jarak jauh atau bisa disebut pembelajaran daring dengan memanfaatkan jaringan internet melalui video konferensi berupa aplikasi Zoom Meating, whatsaap, bahakan melalui situssitus belajar yang sudah ada di internet seperti, google classroom, google formulir, google meet, edomodo, dan aplikasi lainnya.

Temuan pada penelitian ini sejalan dengan beberapa hasil penelitian berikut, yang pertama hasil penelitian Dewi (2020:60) menunjukkan untuk memutus rantai penularan pandemik Covid-19 pembelajaran yang biasanya dilakukan di sekolah sekarang menjadi belajar dirumah dengan menggunakan berbagai macam aplikasi seperti ruang guru, class room, zoom, google doc, google from, maupun melalui grup whatsapp, dan diakses melalui jaringan internet. Kegiatan belajar dapat berjalan baik dan efektif sesuai dengan kreatifitas guru dalam memberikan materi dan soal latihan kepada siswa melalui berbagai aplikasi yang tersedia dan diakses menggunakan jaringan internet. Temuan hasil penelitian yang telah dilakukan di SMP 3 Sungai Lilin mengenai kendala yang dihadapi dalam pembelajaran berbasis TIK dapat disimpulkan bahwa untuk menerapkan pembelajaran berbasis TIK bukanlah suatu hal yang mudah dan pasti memliki kendala untuk mengimplementasikannya kedalam aktifitas sekolah serta sarana prasaran TIK yang lumayan mahal dan tidak bisa 


\section{STRATEGY : Jurnal Inovasi Strategi dan Model Pembelajaran \\ Vol 1. No 1. Juli Tahun 2021 e-ISSN : 2798-5466 P-ISSN : 2798-5725}

langsung dilengkapi tetapi harus memiliki program jangka panjang untuk memenuhi kebutuhan sarana prasarana yang diperlukan dalam menerepkan pembelajaran berbasis TIK.

Hal ini sejalan dengan hasil penelitian yang telah dilakukan oleh Nurvitasari (2018:60) menejelaskan bahwa untuk memenuhi sarana prasarana TIK yang lumayan mahal perlu perhatian serius oleh instansi terkait melalui program yang telah direncanakan untuk memenuhi fasilitas perangkat TIK, diharapkan adanya pendataan dan monitoring mengenai fasilitas perangkat TIK guna menjamin ketersediaan sarana dan prasarana TIK yang mencukupi di setiap sekolah serta pengadaan dan penambahan jumlah fasilitas perangkat TIK guna mendukung proses pembelajaran menjadi lebih maksimal.

Hasil temuan selanjutnya penelitian yang telah dilakukan di SMP 3 Sungai Lilin mengenai kendala yang dihadapi dalam pembelajaran berbasis TIK dapat disimpulkan bahwa ketersedian sebuah jaringan sinyal internet belum merata, kesiapan guru untuk menerpakan pembelajaran berbasis TIk masih banyak kurang pengetahun bagai mana menerapkan pembelajaran berbasis TIK agar lebih menarik, dan belom terbiasanya siswa memanfaatkan TIK sebagai sumber belajar.

Hal ini sejalan dengan hasil penelitian Suriansyah (2015:4) menjelaskan bahwa masih ditemukannya sekolah yang belum tersentuh teknologi informasi terkini, jangankan fasilitas TIK, adapun penyebaran jaringan internet juga belom merata di setiapa desa yang jauh dari kota. Tingkat profesionalisme guru masih belum seluruhnya standar akibatnya strategi pembelajaran inovatif berbasis TIK masih jarang dilakukan. Penggunaan TIK masih cenderung menggunakan TIK sebagai media bukan sebagai sumber belajar. Kalaupun siswa menggunakan TIK lebih banyak menggunakannya sebagai media bukan sebagai sarana penggalian sumber-sumber belajar mutakhir.

Berdasrkan hasil pembahasan diatas dapat disimpulkan bahwa kepala sekolah SMP negeri 3 sungai Lilin melakukan manajemen dan kontrol pengawasan melihat dari segi tantangan dan manfaat apa saja yang didapatkan pada manajemen pembelajaran berbasis TIK. Sehingga kegiatan yang dilaksanakan harus dikontrol sesuai dengan yang direncanakan agar mencapai tujuan pembelajaran yang diinginkan.

\section{KESIMPULAN}

Manajemen pembelajaran berbasis TIK di SMP Negeri 3 Sungai Lilin berkaitan dengan perencanaan, organisasi, koordinasi dan pengawasan melalui peran kepala sekolah yang bertanggung jawab dalam memenuhi sarana prasarana dalam proses pembelajaran berbasis TIK, memberikan dukungan kepada pendidik (guru) dan tenaga pendidik dengan mengadakan pelatihan-pelatihan yang berkaitan dengan pemanfaatan TIK dalam proses pembelajaran. Pemanfaatan TIK yang dapat dirasakan adalah mempermudah dalam mengelola manajemen kelas berupa pembuatan perangkat pembelajaran, silabus , RPP dan mengelola hasil nilai peserta didik dengan mengunakan komputer ataupun laptop serta melalui pemanafaatan TIK dengan berbagai produk yang tersedia dapat dijadikan sebagai sumber belajar bagi pendidik dan peserta didik. Memanfaatkan pembelajaran berbasis TIK pasti memiliki kendala untuk menerapakannya kedalam aktifitas sekolah terutama dalam proses pembelajaran, Dimulai dari memenuhi kebutuhan sarana prasarana TIK, cukup mahalnya sarana prasaran TIK, ketersedian jaringan sinyal internet belum merata, kemampuan guru untuk menerapakan pembelajaran berbasis TIk, penggunaan TIK masih cenderung sebagai media bukan sebagai sumber belajar

\section{DAFTAR PUSTAKA}

Aka, Kukuh Andri. 2017. Pemanfaatan Teknologi Informasi Dan Komunikasi (TIK) Sebagai Wujud Inovasi Sumber Belajar Di Sekolah Dasar. Jurnal Pendidikan. Vol 1. No 2a (28-37)

Bali, M.M.E.I. 2019. Implementasi Media Pembelajaran Berbasis Teknologi Informasi dan Komunikasi Dalam Distance Learning. Journal Tarbiyatuna. Vol 3. No 1 (30-40) 
Budiman, Haris. 2017. Peran Teknologi Informasi Dan Komunikasi Dalam Pendidikan. Journal Pendidikan Islam. Vol 8 No 1 (75-83)

Damayni, Titin. Arafat, Yasir. \& Syaiful, Eddy. 2020. Pengaruh Kepemimpinan Kepala Sekolah dan Motivasi Kerja terhadap Kinerja Guru. Journal of Innovation in Teaching and Instructional Media. Vol 1. No 1 (46-57)

Dewi, Wahyu Aji Fatma. 2020. Dampak Covid 19 Terhadap Implementasi Seperti Pembelajaran Daring Di Sekolah Dasar. Jurnal Ilmu Pendidikan. Vol 2. No 1 (55-61)

Fauziah dan Hedwig, R. 2010. Pengantar Teknologi Informasi. Bandung : Maura Indah Huda, Ikhram Abdaul. 2020. Perkembangan Teknologi Informasi dan Komunikasi (TIK) Terhadap Kualitas Pembelajaran di Sekolah Dasar. Jurnal Pendidikan. Vol 1. No 2 (143-149)

Gasong, Dina. 2018. Belajar dan Pembelajaran. Yogyakarta: Deepublish

Kartika, Sinta. Husni, \& Millah Saepul. 2019. Pengaruh Kualitas Sarana Dan Prasarana Terhadap Minat Belajar Siswa Dalam Pembelajaran Pendidikan Agama Islam. Journal Pendidikan Islam. Vol 7. No 1 (114-126)

Kurniawan, Ari. 2019. Pemanfaatan Teknologi Informasi Dan Komunikasi (Tik) Untuk Pembelajaran Di Smp Negeri 5 Ponorogo, Jawa Timur. Journal Teknodik. Vol 23. No 1(55-64)

Kristiawan, Muhammad. Safitri, Dian. \& Lestari Rena. 2017. Manajemen Pendidikan. Yogyakarta: Deepublish

Maria, Edna \& Sediyono, Eko. 2017. Pengembangan Model Manajemen Pembelajaran Berbasis Tik Di Sekolah Dasar. Journal Manajemen Pendidikan. Vol 4. No 1 (59-71)

Moleong. 2011. Metodologi Penelitian Kualitatif. Bandung: Remaja Karya

Muhibudin, Agus. 2017. Paradigma Pemanfaatan Teknologi Informasi ( It ) Dalam Proses Pembelajaran Pai Untuk Meningkatkan Mutu Pendidikan ( Study Di Smp Negeri 2 Ciledug Kabupaten Cirebon). Jurnal Ilmiah Indonesia. Vol 2. No 2 (1-7).

Nurvitasari, Evy. 2018. Pemanfaatan Teknologi Informasi Dan Komunikasi Oleh Guru Dalam Pembelajaran Kimia Sma Di Distrik Merauke. Journal Magistra. Vol 5. No 1 (48-61)

Partono. 2020. Manajemen Stratejik Pemanfaatan Teknologi Informasi dan Komunikasi untuk Peningkatan Mutu Pembelajaran SMK Ciledug Al Musaddadiyah dan SMKN 1 Garut. Journal Maps. Vol 3. No 2 (109-119)

Rusman. 2013. Pembelajaran Berbasis Teknologi Informasi dan Komunikasi, PT. Raja grafindo Persada, Jakarta, 2013

Sugiyono. 2017. Metode penelitian Kuantitatif, kualitatif, dan R\&D. Bandung: Alfabeta

Suriansyah, Ahmad. 2015. Pengembangan Pembelajaran Berbasis TIK (Proses Dan Permasalahannya). Journal Paradigma. Vol 10. No 2 (1-6)

Utami Yulia. 2017. Pengaruh Pemanfaatan Media Pembelajaran Proyektor LCD Menggunaka Program Power Point Terhadap Hasil Belajar Siswa Dalam Menuntukan Volume Kubus Dan Balok Pada Bangun Ruang. Journal Mantik Penusa. Vol 1. No 1 (52-58)

Utamy, Rahmah. Ahmad, Syarwani. \& Eddy, Syaiful. 2020. Implementasi Manajemen Sumber Daya Manusia. Journal of Education Research. Vol 1. No 3 (226-236)

Wardani, Erika Sherly. 2014. Peran kepala sekolah sebagai pemimpin pembelajaran dalam upaya penigkatan pembelajaran berbasis TIK di SMA Negeri Mojoagung Jombang. Jurnal Manajemen Pendidikan. Vol 4. No 4 (201-206

Winda, Novia. 2016. Implementasi Kurikulum 2013 dalam Pembelajaran Bahasa Indonesia Berbasis Teknologi Informasi dan Komunikasi. Journal Bahasa, Sastra, dan Pengajarannya. Vo. 1. No 1 (87-94)

Wirastuti, Lusiana. 2020. Manajemen Kelas Dan Pembelajaran: Dampaknya Terhadap Efektivitas Proses Pembelajaran. Journal Edum. Vol 3. No 1 (11-18)

Zulkarnain, Muhammad Rizki. 2015. Manajemen Kelas Berbasis Teknologi Informasi dan Komunikasi. Journal Paradigma. Vol 1. No 2 (75-77) 